\title{
PENGALAMAN KOMUNIKASI PELAKU BISNIS KELUARGA DALAM MENGEMBANGKAN BISNIS KULINER DI KOTA SUKABUMI
}

\author{
Rima Nurani Sukma, Suwandi Sumartias, Nuryah Asri Sjafirah* \\ Yayasan Sosial dan Pendidikan At-tawazun
}

\begin{abstract}
ABSTRAK
Keluarga sebagai sistem lebih bersifat emosional, karena disatukan oleh ikatan mendalam yang mempengaruhinya dalam berbisnis. Komunikasi bisnis keluarga memiliki hubungan yang erat dengan pertentangan, perbedaan serta penolakan pendapat atau ide, ketidakpercayaan antara sesama anggota, bahkan memicu konflik. Penelitian ini menggunakan pendekatan jenis penelitian kualitatif dengan metode penelitian fenomenologi. Penentuan sumber data penelitian, menggunakan teknik purposive dengan 5 informan yang mengelola bisnis keluarga dibidang kuliner yang telah berkembang. Penelitian ini bertujuan untuk mengidentifikasi motif-motif yang mendorong pelaku melakukan bisnis keluarga, mendeskripsikan makna komunikasi bisnis keluarga serta mendeskripsikan aktivitas komunikasi bisnis yang dilakukan oleh pelaku bisnis keluarga dalam menjalankan bisnis kulinernya. Hasil penelitian ini adalah motif yang mendorong pelaku untuk melakukan bisnis keluarga diantaranya: motif kepatuhan (obedience motive), motif aktualisasi diri (self actualization motive), motif ekonomi (economic motive) dan motifbakat (aptitude motive). Makna komunikasi bisnis keluarga bagi pelaku adalah sebuah tantangan dan kepatuhan. Makna yang dikonstruksi tersebut, dapat dinetralisir dengan melakukan obrolan ringan, pertemuan bisnis keluarga, rapat keluarga yang dapat menghasilkan beberapa point, seperti pengambilan keputusan yang dapat dilakukan secara diskusi dan professional, melakukan pelaporan kegiatan bisnis, dan pemecahan dari perbedaan pendapat bahkan konflik. Aktivitas Komunikasi pelaku bisnis keluarga mencakup promosi, membangun hubungan dengan karyawan, supliyer dan memfasilitasi pelanggan restoran dengan acara karaoke, happy hours, nonton bareng, serta membina hubungan dengan partner bisnis dengan membangun perjanjian kerjasama pembukaan cabang baru.
\end{abstract}

Kata-kata kunci: Komunikasi bisnis, keluarga, pengalaman, bisnis keluarga, fenomenologi

\section{THE IMPRESSION OF COMMUNICATIONS FAMILY BUSINESSES IN DEVELOPING CULINARY BUSINESS AT SUKABUMI}

\begin{abstract}
Family as a system is more emotional, because united by deep bonds that influence on business. Family business communications has a close with opposition, difference and rejection of opinion or idea, distrust between a fellow member, even lead to conflict. Using qualitatve approach with phenomenological research methods. Determination source of research data, using purposive technique to with 5 informants who manage family business, which has been growing culinary field. The goal of this research is to identify the motives that encourages actors to do family business, described the meaning of family business communications and described the activity of business communications conducted by actors in developing their own family culinary business. The results of this research is, the motive that encourages actors to conducted family business is: obedience motive, self actualization motive, economic motive and aptitude motive. The meaning of family business communications for actors is a challenge and submission. Meaning constructed can be neutralized by doing chitchat, family business meeting, and family conference which can generate several points like, making decisions that can be done with a discussion or professionally, business reporting, responding argument, and managemen conflict. The activities of business communication is businesses promotion, building relationships with employees, suplyer, and facilitate costumer by karaoke events, happy hours, movie time, and building coorporate agreement with business partners for opening new franchise.
\end{abstract}

Keywords: Business communication, family, impression,family business, phenomenology

\footnotetext{
* Korespondensi: Rima Nurani Sukma, S.I.Kom., M.I.Kom. Yayasan Sosial dan Pendidikan At-tawazun, Jl. H.M. Dadang Surade Sukabumi 43179. Email: rimanurani27@gmail.com
} 


\section{PENDAHULUAN}

Dalam menjalankan roda perusahaan keluarga selalu ada tarik ulur, mana yang lebih dominan antara perusahaan (bisnis) dan keluarga. Idealnya, ada keseimbangan. Keluarga dan bisnis sejatinya adalah dua hal. Masingmasing merupakan sistem yang mempunyai elemen-elemen tersendiri. Keluarga sebagai sistem lebih bersifat emosional, karena disatukan oleh ikatan mendalam yang mempengaruhinya dalam berbisnis. Diantaranya, keluarga sangat menjunjung tinggi loyalitas dan nurturing. Selain itu keluarga juga cenderung konservatif, meminimalisir perubahan untuk menjaga mereka agar tetap utuh.

Berdasarkan Kitab Undang-Undang Hukum Perdata, persaudaran dalam keluarga ada empat golongan. Golongan pertama ialah keluarga dalam garis lurus ke bawah (anakanak beserta keturunan mereka beserta suami/ istri. Golongan kedua, terdiri atas keluarga dalam garis lurus ke atas (orang tua dan saudara, baik laki-laki maupun perempuan, serta keturunan mereka). Golongan ketiga terdiri atas kakek, nenek, dan leluhur selanjutnya ke atas. Golongan keempat terdiri dari anggota keluarga dalam garis ke samping dan sanak keluarga lainnya sampai derajat keenam. Penggolongan semacam ini lazimnya terkait dengan urutan keutamaan dalam pewarisan.

Menurut Azjen \& Fishbein (1985), niat seseorang dalam menjalankan bisnis dipengaruhi sejumlah faktor yang dapat dilihat dalam suatu kerangka integral yang melibatkan berbagai faktor internal, faktor eksternal dan faktor kontekstual. Faktor internal berasal dari dalam diri pelaku berupa karakter sifat, maupun faktor sosio-demografi seperti umur, jenis kelamin, pengalaman kerja, latar belakang keluarga dan lain-lain yang dapat mempengaruhi perilaku kewirausahaan seseorang. Sedangkan faktor eksternal berasal dari luar diri pelaku yang dapat berupa unsur dari lingkungan sekitar dan kondisi kontekstual.

Untuk itu sejumlah atribut personality seperti adanya kebutuhan berprestasi, internal locus of control yang kuat, tingginya kreativitas dan inovasi, ikut berperan dalam membentuk niat pelaku untuk berwirausaha. Demikian juga faktor sikap seseorang dalam memandang kegiatan berwirausaha juga dipercayai akan membentuk niat kewirausahaan. Sedangkan faktor kontekstual adalah dukungan akademik, dukungan sosial dan kondisi lingkungan usaha (Gurbuz \& Aykol, 2008: 52).

Bisnis keluarga yang berkembang, yang menjadi perhatian peneliti adalah bisnis di bidang kuliner. Industri kuliner merupakan bidang usaha yang sangat berpengaruh terhadap pemenuhan kebutuhan makanan dan minuman masyarakat. Potensi dari industri ini sangat besar mengingat setiap tahunnya selalu berkembang sesuai dengan permintaan pasar. Industri kuliner merupakan tiang perekonomian rakyat. Bahkan, usaha seperti ini yang tidak goyah dengan berbagai krisis moneter yang melanda perekonomian nasional jika managemen dan produksinya dilakukan secara profesional.

Tidak banyak bisnis kuliner yang mengalami perkembangan, beberapa usaha kuliner lain lebih memilih mempertahankan cara berjualan dengan menjajakan makanan di pinggiran jalan, tanpa terpikir untuk membangun ulang warung makan tersebut. Disatu sisi, mereka memanfaatkan kekhasan dari cita rasa kuliner yang mereka pikir sangat bisa diandalkan untuk tetap bertahan. Dengan cita rasa yang khas dan harga yang pas, mereka yakini komunikasi dari mulut ke mulut dapat berjalan begitu saja. Oleh karena itu, komunikasi bisnis dalam keluarga sangatlah penting sebagai kesiapan membicarakan dengan terbuka setiap hal dalam keluarga, baik yang menyenangkan maupun yang tidak menyenangkan, juga siap menyelesaikan masalah bisnis keluarga dengan pembicaraan yang dijalani dalam kesabaran, kejujuran dan keterbukaan.

Untuk menyelaraskan keinginan keluarga dengan persyaratan bisnis, perusahaan keluarga perlu menyadari bahwa perusahaan didirikan berdasarkan hubungan genetik, bahwa keluarga memiliki bisnis tersebut dan bahwa keluarga sangat terlibat dalam manajemen. Menjaga harmoni (harmony preservation) merupakan tugas pendiri dan sangat penting untuk menghindari perselisihan yang berdampak pada operasi perusahaan sehari-hari.

Pengalaman komunikasi bisnis keluarga pada setiap individu bersifat relatif dan 
Dalam penelitian kuantitatif, untuk mendapatkan data yang valid dan reliabel yang diuji validitas dan reliabilitasnya adalah instrumen penelitiannya, sedangkan dalam penelitian kualitatif, yang diuji adalah datanya. Oleh karena itu, Susan Staick (dalam Sugiyono, 2013: 270) menyatakan bahwa penelitian kuantitatif lebih menekankan pada aspek reliabilitas, sedangkan penelitian kualitatif lebih pada aspek validitas.

Pada penelitian kualitatif, temuan atau data dapat dinyatakan valid apabila tidak adanya perbedaan antara yang dilaporkan peneliti dengan apa yang sesungguhnya terjadi pada obyek yang diteliti. Tetapi perlu diketahui bahwa kebenaran realitas data menurut penelitian kualitatif tidak bersifat tunggal, tetapi jamak dan tergantung pada konstruksi manusia, dibentuk dalam diri seorang sebagai hasil proses mental tiap indivdiu dengan berbagai latar belakangnya (Sugiyono, 2013: 272). Jadi pengertian reliabilitas pada penelitian kualitatif berbeda dengan kuantitatif karena realitas selalu berubah sehingga tidak ada yang konsisten dan berulang seperti semula.

Dalam penelitian ini pengujian keabsahan data penelitian dilakukan dengan tiga cara tri-angulasi, pengecekan anggota, dan uraian rinci. Triangulasi adalah teknik pemeriksaan keabsahan data yang memanfaatkan pemeriksaan melalui sumber lainnya. Denzin (dalam Moleong, 2013: 76) membedakan empat macam triangulasi sebagai teknik pemeriksaan yang memanfaatkan penggunan sumber, metode, penyidik dan teori.

Di dalam penelitian ini peneliti menggunakan metode Member check dalam Pengecekan dengan anggota yang terlibat dalam proses pengumpulan data sangat penting dalam pemeriksaan derajat kepercayaan. Yang dicek dengan anggota yang terlibat meliputi data, kategori analitis, penafsiran, dan kesimpulan. Para anggota yang terlibat yang mewakili rekan-rekan mereka dimanfaatkan untuk memberi reaksi dari segi pandangan dan situasi mereka sendiri terhadap data yang telah diorganisasikan oleh peneliti.

Teknik ini menuntut peneliti agar melaporkan hasil penelitiannya sehingga uraiannya itu dilakukan seteliti dan secermat mungkin yang menggambarkan konteks tempat penelitian diselenggarakan. Uraiannya harus mengungkapkan secara fokus segala sesuatu yang dibutuhkan oleh pembaca agar mereka dapat memahami temuan-temuan yang diperoleh. Temuan itu tentunya bukan bagian dari uraian rinci, melainkan penafsirannya yang dilakukan dalam bentuk uraian rinci dengan segala macam pertanggungjawaban berdasarkan kejadian-kejadian nyata.

\section{HASIL DAN PEMBAHASAN}

Pertama, motif pelaku bisnis keluarga. Untuk memahami makna tindakan manusia, dibutuhkan metode verstehen yang mengarah pada suatu tindakan bermotif pada tujuan yang hendak dicapai. Menurut Collin (2002: 209), tindakan manusia adalah suatu tindakan subjektif yang merujuk pada suatu motif tujuan yang sebelumnya mengalami intersubjektif yang berupa hubungan interaksi face to face antarpersona yang bersifat unik. Tindakan rasional semacam itu adalah suatu tindakan yang bertujuan atas dasar rasional nilai yang berlaku dan bersifat efektual, yakni tindakan yang terkait dengan kemampuan intelektual dan emosi, serta berdasar atas pemahaman makna subjektif dari aktor itu sendiri (Basrowi \& Sukidin 2002, dalam Sobur, 2013: 56).

Dalam penelitian ini, penulis mengidentifikasikan motif yang mendorong para pelaku untuk melakukan bisnis keluarga, melalui jawaban yang diberikan oleh para informan. Para pelaku bisnis keluarga mengungkapkan jawaban berbeda-beda sesuai latar belakang yang mereka miliki. Berdasarkan jawaban dari para pelaku bisnis keluarga, peneliti menemukan beberapa motif yang melatarbelakangi para pelaku bisnis untuk terjun dalam bisnis keluarganya, diantaranya adalah motif kepatuhan (obedience motive), motif aktualisasi diri (self actualization motive), motif ekonomi (economic motive) dan motif bakat (aptitude motive). Motif-motif tersebut dapat divisualisasikan dengan gambar berikut: 
pengertian. Sedangkan tujuan pokok dari komunikasi ini adalah memprakarsai dan memelihara interaksi antara satu anggota dengan anggota lainnya sehingga tercipta komunikasi yang efektif.

Komunikasi dalam keluarga juga dapat diartikan sebagai kesiapan membicarakan dengan terbuka setiap hal dalam keluarga baik yang menyenangkan maupun yang tidak menyenangkan, juga siap menyelesaikan masalah-masalah dalam keluarga dengan pembicaraan yang dijalani dalam kesabaran dan kejujuran serta keterbukaan (Friendly, 2002: 1).

Terlihat dengan jelas bahwa dalam keluarga adalah pasti membicarakan hal-hal yang terjadi pada setiap individu, komunikasi yang dijalin merupakan komunikasi yang dapat memberikan suatu hal yang dapat diberikan kepada setiap anggota keluarga lainnya. Dengan adanya komunikasi, permasalahan yang terjadi diantara anggota keluarga dapat dibicarakan dengan mengambil solusi terbaik.

Makna komunikasi keluarga menurut pelaku bisnis keluarga, divisualisaikan dalam gambar sebagai berikut:

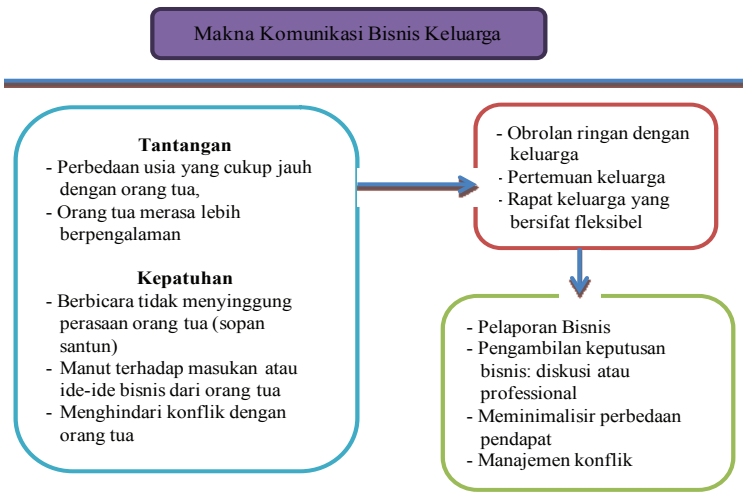

Gambar 3. Model Konstruksi Makna Komunikasi Bisnis Keluarga

Sumber: Penelitian, 2015

Komunikasi keluarga merupakan sebuah tantangan bagi sebagian pelaku bisnis keluarga. Perbedaan usia antara anak dan orang tua yang cukup jauh dimana mereka harus berkolaborasi dalam tugas-tugas pengembangan bisnis. Personel muda yang idealis dihadapkan dengan anggota keluarga senior yang cenderung menghadapi persoalan bisnis berkaca pada pengalaman hidup dan bukan pada pengalaman professional mereka. "Egoisme masing-masing, karena mereka merasa lebih tua, merasa lebih berpengalaman." Kecenderungan orang tua yang ingin lebih dihargai, merasa lebih tahu dan lebih berpengalaman dalam hidup, menjadikan mereka merasa selalu benar.

Selain tantangan, makna komunikasi keluarga bagi pelaku bisnis keluarga adalah kepatuhan. Kepatuhan dalam arti berbicara tidak menyinggung perasaan orang yang lebih tua, "Misalnya seperti saya memberitahu ibu saya sendiri, kalau cara komunikasinya salah itu berasanya seperti kurang ajar sama Ibu saya." Selain sopan santun dalam berkomunikasi, manut atau patuh terhadap masukan atau ide-ide bisnis pun terasa penting demi menghindari konflik antar anggota keluarga. Maksudnya, pelaku bisnis keluarga tetap berhak mengeluarkan gagasan atau ideide bisnis, namun tetap dalam batasan-batasan tertentu.

Makna tantangan dan kepatuhan yang dikontruksi oleh pelaku bisnis keluarga, dapat dinetralisir dengan berbagai cara, yaitu diantaranya dengan obrolan ringan, pertemuan keluarga, dan rapat keluarga. Menjaga hubungan bisnis dalam keluarga, berkomunikasi dengan gaya tutur yang sederhana layaknya sebuah penjelasan ringan itu sangat bermanfaat untuk mencairkan suasana, obrolan ringan antara anak dan orang tua yang merujuk pada kehidupan pribadi hingga berakhir pada obrolan mengenai pengembangan-pengembangan bisnis keluarga.

Pertemuan bisnis dalam keluarga biasanya lebih informal, dilakukan antara ayah atau ibu kepada anak, bahkan kakak kepada adik yang terlibat dalam bisnis keluarga dengan tidak mengenal ruang dan waktu. Percakapan dalam pertemuan keluarga tersebut mencakup pengambilan keputusan, pelaporan, pemecahan dari perbedaan pendapat. Sedangkan rapat keluarga yang bersifat lebih fleksibel dilakukan setidaknya 2 minggu sekali atau sebulan sekali tergantung kepentingan bisnis.

Dalam obrolan ringan dengan keluarga, pertemuan, dan rapat keluarga, ada beberapa poin yang dihasilkan, diantaranya pengambilan keputusan, pelaporan, meminimalisir perbedaan pendapat, dan manajemen konflik.

Dalam hubungan keluarga yang begitu kompleks dengan unsur bisnis di dalamnya, pengambilan keputusan merupakan hal yang sangat penting. Para pelaku bisnis keluarga cenderung lebih menghormati dengan diskusi 
subjektif. Komunikasi bisnis keluarga juga memiliki hubungan yang erat dengan konflik. Dalam komunikasi bisnis yang dilakukan antar anggota keluarga, pertentangan dan perbedaan serta penolakan pendapat atau ide, ketidakpercayaan antara sesama anggota adalah suatu hal yang wajar terjadi. Pertentangan, perbedaan dan penolakan dapat menjadi sumber konflik dalam konteks komunikasi bisnis keluarga. Tema minat juga seringkali dikomunikasikan oleh anggota keluarga atau anak terhadap orang tua.

Akan lain kondisinya jika kecenderungan lebih ditekankan ke luar dengan prinsip "apa yang baik bagi perusahaan akan baik bagi keluarga." Dalam prinsip ini terkandung pesan bahwa ikatan emosi dan hubungan personal adalah modal, bukan potensi konflik. Dengan prinsip ini ikatan emosional yang sangat kuat dalam keluarga justru berkontribusi sebagai penopang bagi kuatnya budaya perusahaan. Berpegang pada norma bisnis yang diantaranya berupa pembagian peran yang jelas, transparansi, dan pay by performance, niscaya konflik keluarga bisa dihindari. Hubungan kekeluargaan yang sifatnya permanen menjadi bibit loyalitas dalam perusahaan.

Pengalaman yang disadari oleh individu dan menjadi bagian dari dimensi kesadaran diri individu dikaji dengan metode penelitian fenomenologi Edmund Husserl. Motif yang ada dalam diri individu sebagai bagian dari pengalaman individu dalam melakukan tindakan sosial dapat dikaji melalui teori fenomenologi dari Alfred Schutz (1970). Pelaku bisnis keluarga adalah aktor yang melakukan tindakan sosial bersama aktor lainnya sehingga memiliki kesamaan dan kebersamaan dalam ikatan makna intersubjektif. Para aktor yang memiliki historisitas dan dapat dilihat dalam bentuk yang alami. Menurut pemikiran Schutz, pelaku bisnis keluarga sebagai aktor yang mungkin memiliki salah satu dari dua motif, yaitu motif yang berorientasi ke masa depan (in order to motive) dan motif yang berorientasi ke masa lalu (because motive). Kedua motif tersebut akan menentukan penilaian terhadap dirinya sendiri dalam statusnya sebagai family owned business.

Dalam penelitian ini, penulis mencoba mengangkat pengalaman komunikasi bisnis keluarga dalam mengembangkan bisnis kuliner. Pengalaman itu mencakup motif terkait minat mereka dalam meneruskan warisan bisnis kuliner, pengalaman komunikasi bisnis keluarga dalam menghidari konflik dan mengeratkan ikatan emosional yang positif, serta pengalaman komunikasi bisnis dalam mempertahankan bisnis kuliner keluarga dalam menghadapi persaingan pasar. Kerangka penelitian dirumus-kan dalam bagan berikut:

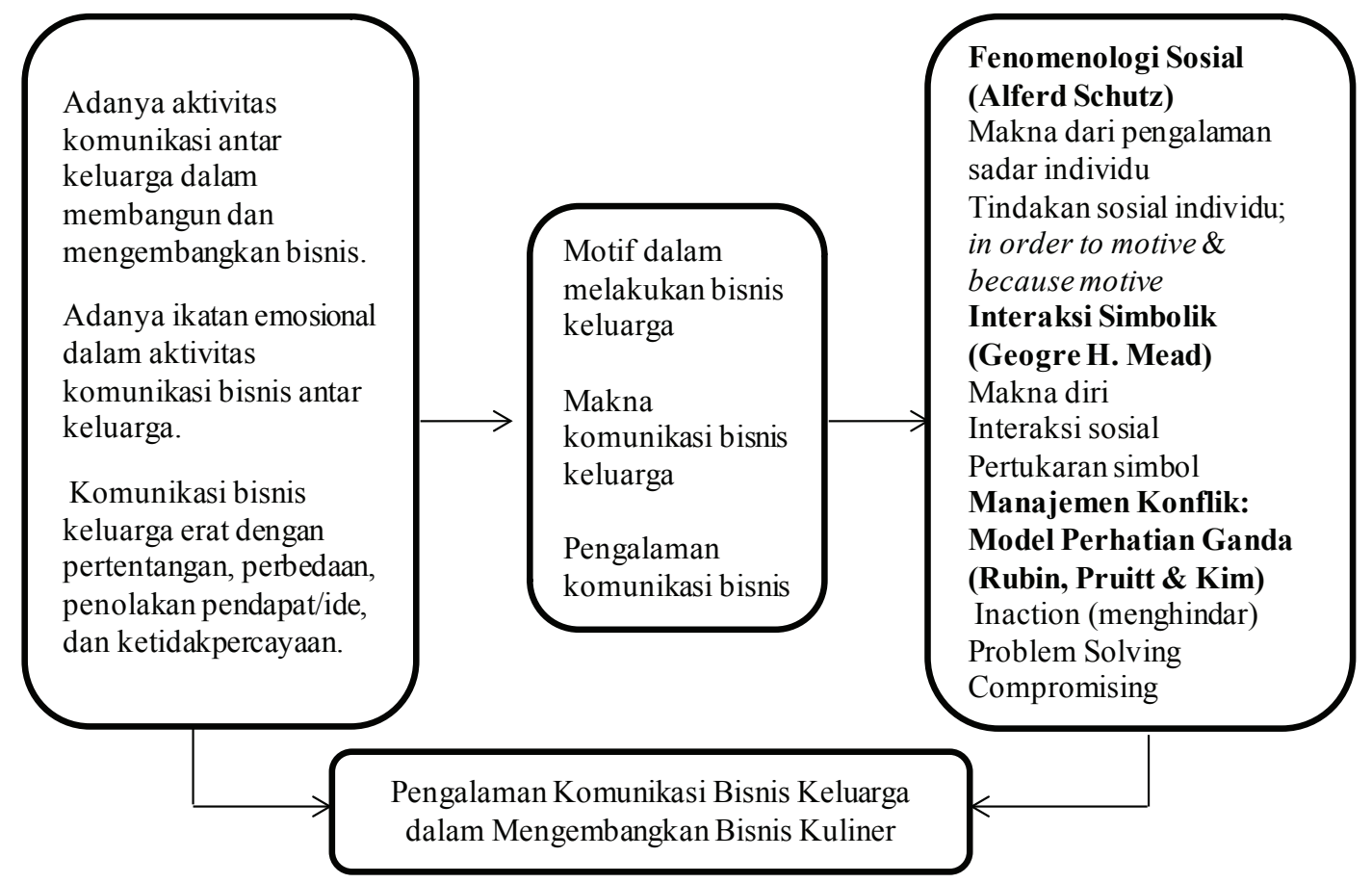

Gambar 1 Bagan Kerangka Pemikiran 


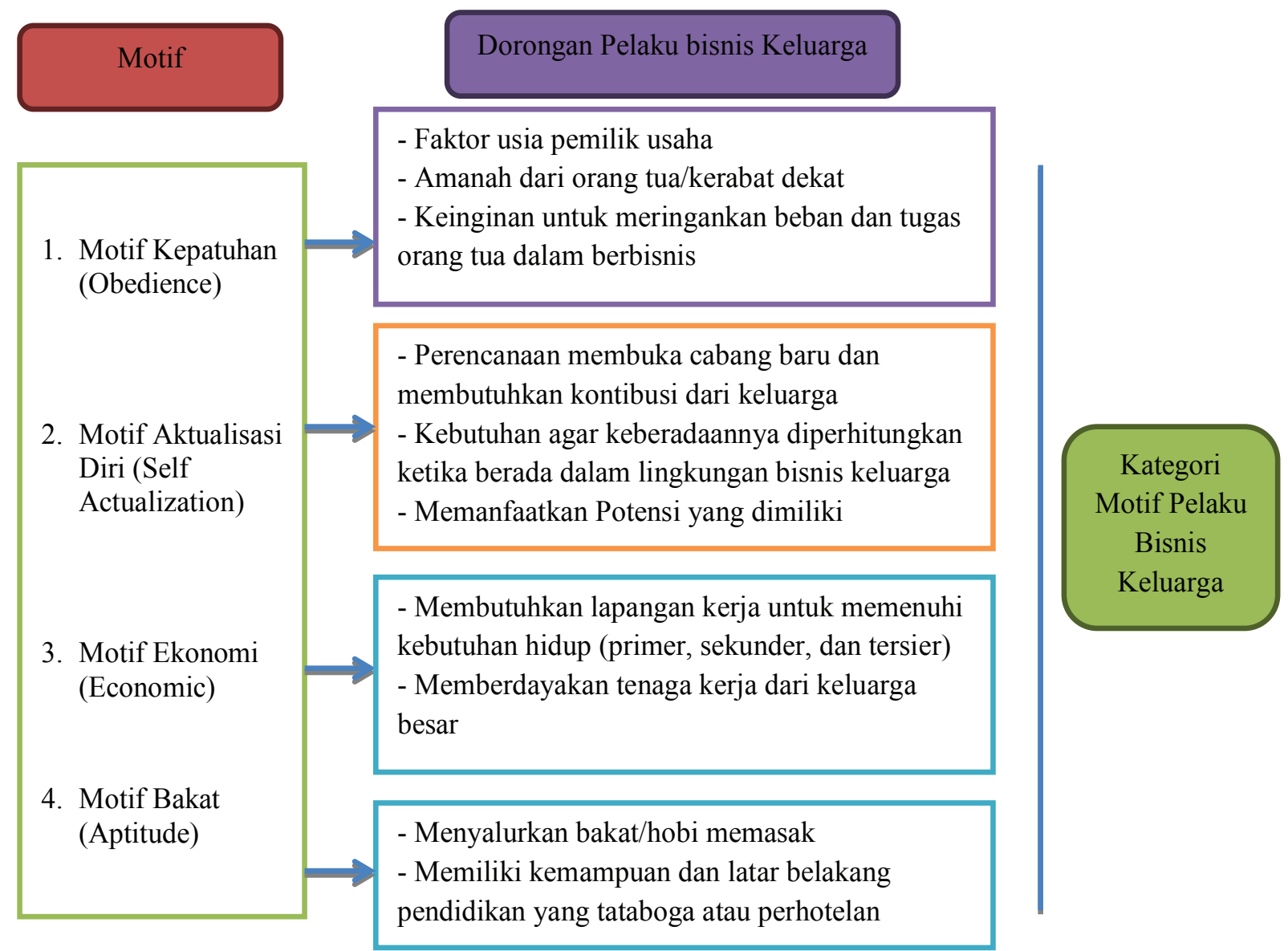

Gambar 2. Model Motif Pelaku Bisnis dalam Mengembangkan Bisnis Keluarga

Sumber: Penelitian, 2015

Para pelaku bisnis terjun dalam bisnis keluarga atas dasar kepatuhan terhadap orang tua atau kerabat yang memerlukan kontribusi mereka. Sebagai seorang anak yang ingin membahagiakan orang tua, atau sebagai sanak keluarga yang ingin menjalankan amanah dan membantu meringankan tugas-tugas mereka karena faktor usia dan keadaan tertentu. Ditunjang dengan faktor latar belakang pendidikan yang berkaitan dengan pengelolaan bisnis, mereka merasa cukup percaya diri untuk terjun mengelola bisnis keluarga yang dipercayakan kepada mereka.

Menurut Kamus Besar Bahasa Indonesia, patuh adalah suka menurut perintah, taat pada perintah, sedangkan kepatuhan adalah perilaku sesuai aturan dan berdisiplin. Sedangkan menurut Ali dalam Slamet (2007: 109), kepatuhan berasal dari kata dasar patuh, yang berarti disiplin dan taat. Patuh adalah suka menurut perintah, taat pada perintah atau aturan. Sedangkan kepatuhan adalah perilaku sesuai aturan dan berdisiplin.

Teori kepatuhan telah diteliti pada ilmuilmu sosial khususnya dibidang psikologis dan sosiologi yang lebih menekankan pada pentingnya proses sosialisasi dalam mempengaruhi perilaku kepatuhan seorang individu. Menurut Tyler (Saleh, 2004) terdapat dua perspektif dalam literatur sosiologi mengenai kepatuhan, yaitu instrumental dan normatif.

Perspektif instrumental mengasumsikan individu secara utuh didorong oleh kepentingan pribadi dan tanggapan terhadap perubahanperubahan yang berhubungan dengan perilaku. Perspektif normatif berhubungan dengan apa yang orang anggap sebagai moral dan berlawanan dengan kepentingan pribadi.

Sebagai seseorang yang terjun dalam bisnis keluarga, kepatuhan adalah suatu hal yang amat bermoral. Dalam hubungan keluarga yang emosional, dimana kepatuhan adalah suatu keharusan untuk menaati perintah dan menciptakan hubungan yang harmonis. Keberhasilan dalam keluarga diukur dalam artian harmoni, kesatuan, dan perkembangan individu yang bahagia dengan harga diri yang solid dan positif. 


\section{METODE PENELITIAN}

Pendekatan penelitian ini menggunakan jenis penelitian kualitatif yang metode untuk mengeksplorasi dan memahami makna yang dianggap berasal dari masalah sosial atau kemanusiaan. Proses penelitian ini melibatkan upaya-upaya penting seperti mengajukan pertanyaan-pertanyaan dan prosedur-prosedur, mengumpulkan data yang spesifik dari para partisipan, menganalisis data secara induktif dan menafsirkan makna data (Creswell, 2014: 4-5).

Bogdan dan Taylor (dalam Moleong, 2013:4) mendefinisikan metodologi kualitatif sebagai prosedur penelitian yang menghasilkan data deskriptif berupa kata-kata tertulis atau lisan dari orang-orang dan perilaku yang dapat diamati. Pendekatan ini diarahkan pada latar dari individu tersebut secara holistik (utuh).

Menurut Jane Richie, penelitian kualitatif adalah upaya untuk menyajikan dunia sosial, dan perspektifnya di dalam dunia, dari segi konsep, perilaku, persepsi dan persoalan tentang manusia yang diteliti. Maka kesimpulannya, penelitian kualitatif adalah penelitian yang memahami fenomena tentang apa yang dialami oleh subjek penelitian misalnya perilaku persepsi, motivasi, tindakan secara holistic, dan dengan cara deskripsi dalam bentuk kata-kata dan bahasa, pada suatu konteks khusus yang alamiah dan dengan memanfaatkan berbagai metode alamiah (Moleong, 2007: 6).

Metode penelitian yang digunakan dalam penelitian ini adalah fenomenologi. Fenomenologi merupakan pandangan berpikir yang menekankan pada fokus kepada pengalaman-pengalaman subjektifmanusiadan interpretasi-interpretasi dunia. Tujuan utama fenomenologi adalah mempelajari bagaimana fenomena dialami dalam kesadaran, pikiran dan tindakan, seperti bagaimana fenomena tersebut bernilai atau diterima secara entetis. Fenomenologi mencoba mencari pemahaman bagaimana manusia mengkonstruksi makna dan konsep-konsep penting, dalam kerangka intersubjektivitas.

Fenomenologi mempelajari struktur pengalaman sadar, bersama dengan kondisikondisi yang relevan. Sehingga fenomenologi akan memimpin pada latar belakang dan kondisi-kondisi dibalik sebuah pengalaman. Pusat dari stuktur kesadaran adalah "kesengajaan," yakni bagaimana makna dan isi pengalaman terhubung langsung dengan objek. (Kuswarno, 2013: 23).

Pada dasarnya fenomenologi mempelajari struktur tipe-tipe kesadaran, yang terentang dari persepsi, gagasan, memori, imajinasi, emosi, hasrat, kemauan, sampai tindakan, baik itu tindakan sosial maupun dalam bentuk bahasa. Struktur dan bentuk kesadaran ini yang dinamakan Husserl dengan "kesengajaan", yang terhubung dengan sesuatu. Struktur kesadaran dalam pengalaman ini yang pada akhirnya membuat makna dan menentukan isi dari pengalaman (content of experience). "Isi" yang sama sekali berbeda dengan "penampakannya" karena sudah ada penambahan makna padanya. Kesadaran yang didefinisikan sebagai keadaan yang memberikan sudut pandang pengalaman dari orang pertama.

Dalam penelitian ini dilakukan teknik pengumpulan data untuk mendapatkan keterangan yang diperlukan sebagai pembahasan masalah dalam penelitian. Pengambilan data yang dilakukan dengan cara teknik wawancara mendalam, teknik observasi, teknik dokumenter.

Wawancara mendalam secara umum adalah proses memperoleh keterangan untung tujuan penelitian dengan cara tanya jawab sambil bertatap muka antara pewawancara denganinformanatauorangyangdiwawancarai, dengan atau tanpa menggunakan pedoman (guide) wawancara, dimana pewawancara dan informan terlibat dalam kehidupan sosial yang relatif lama. Materi wawancara adalah tema yang ditanyakan kepada informan, berkisar antara masalah atau tujuan penelitian. (Burgin, 2009: 108)

Yang dimaksud teknik observasi adalah metode pengumpulan data yang diguanakan untuk menghimpun data penelitian melalui pengamatan dan pengindraan. Oleh karena itu observasi adalah kemampuan seseorang untuk menggunakan pengamatannya melalui hasil kerja pancaindra mata serta dibantu dengan pancaindra lainnya (Burgin, 2009: 115).

Pada intinya teknik dokumenter adalah metode yang digunakan untuk menelusuri data historis. Baiknya sejumlah besar fakta 
Dua dari 5 pelaku bisnis keluarga dipercayakan untuk mengelola keuangan. Hal ini selaras dengan pernyataan John L. Ward dan Craig E. Arnoff, bahwa suatu perusahaan dinamakan perusahaan keluarga apabila terdiri dari dua atau lebih anggota keluarga yang mengawasi keuangan perusahaan. Sedangkan menurut Robert G. Donnelley (2002) suatu organisasi dinamakan perusahaan keluarga apabila paling sedikit ada keterlibatan dua generasi dalam keluarga itu dan mereka mempengaruhi kebijakan perusahaan.

Ditinjau dari hasil penelitian, dapat disimpulkan bahwa beberapa pelaku bisnis keluarga memiliki motif kepatuhan atas dasar taat pada perintah. Memosisikan diri sebagai anak atau saudara kandung, yang berniat membantu mengelola dan mengembangkan bisnis keluarga mereka.

Selanjutnya para pelaku bisnis keluarga terjun dalam bisnis keluarga, guna untuk memenuhi kebutuhan aktualisasi dirinya. Abraham Maslow mengatakan manusia di dorong oleh kebutuhan-kebutuhan universal dan dibawa sejak lahir. Kebutuhan ini tersusun dalam tingkatan-tingkatan dari yang terendah sampai tertinggi. Kebutuhan paling rendah dan paling kuat harus dipuaskan terlebih dahulu sebelum muncul kebutuhan tingkat selanjutnya.

Menurut konsep Hirarki Kebutuhan Abraham Maslow, manusia didorong oleh kebutuhan-kebutuhan universal dan dibawa sejak lahir. Kebutuhan ini tersusun dalam tingkatan-tingkatan dari yang terendah sampai tertinggi. Kebutuhan paling rendah dan paling kuat harus dipuaskan terlebih dahulu sebelum muncul kebutuhan tingkat selanjutnya.

Aktualisasi diri adalah suatu kebutuhan untuk mengungkapkan diri yaitu merupakan kebutuhan manusia yang paling tinggi. Kebutuhan ini akan muncul apabila kebutuhankebutuhan yang ada di bawahnya telah terpuaskan dengan baik. Kebutuhan aktualisasi ditandai sebagai hasrat individu untuk menjadi orang yang sesuai dengan keinginan dan potensi yang dimilikinya, atau hasrat dari individu untuk menyempurnakan dirinya melalui pengungkapan segenap potensi yang dimilikinya.

Keinginan untuk mengaktualisasi diri ada pada diri masing-masing pelaku bisnis keluarga, bahwa motivasi atau dorongan terhadap aktualisasi diri itu adalah bawaan, bahwa setiap pelaku mempunyai suatu keinginan yang inheren, yang kita bawa bersama lahir, yaitu berada demi keberadaan itu, berbuat demi perbuatan itu, merasa demi perasaan itu, yaitu aktualisasi diri.

Kebutuhan untuk mengaktualisasi diri pun dirasakan oleh salah satu informan penelitian yang memiliki latar belakang Perhotelan. Restoran keluarga yang baru membuka cabang, membuatnya tergerak untuk ikut berkontribusi memanfaatkan ilmu yang ia punya, "Karena memang dari awal SOP nya masih SOP standar apa adanya. Sedangkan saya kan memang pengalamannya 8 tahun di hotel, jadi saya coba implementasi aja, apa yang saya dapet dulu di hotel atau di restoran, dikembangkan di bisnis keluarga sendiri...".

Mengaktualisasikan diri merupakan salah satu kebutuhan yang diharapkan dapat terpenuhi oleh para pelaku bisnis keluarga. Adanya keinginan untuk mengaktualisasikan diri merupakan wujud bahwa pelaku adalah pribadi yang keberadaannya diperhitungkan ketika berada dalam lingkungan sosialnya, karena dengan aktualisasi diri yang tepat, pelaku dapat menggunakan kontrol dalam kehidupan mereka, lebih mengembangkan respek diri dan dengan demikian dapat lebih memahami akan keberadaan diri yang sebenarnya. Selain itu, melalui aktualisasi diri pelaku akan lebih mengenal tentang dirinya sendiri dan bagaimana memanfaatkan potensi-potensi yang positif yang ada pada dirinya.

Selain itu, terjun dalam bisnis keluarga merupakan suatu usaha untuk memenuhi kebutuhan hidup bagi beberapa pelaku bisnis keluarga. Menurut pandangan salah satu informan yang mengelola restoran keluarga, terjun mengelola bisnis kakak iparnya dengan melibatkan keluarga besarnya yang lain, merupakan sebuah pemberdayaan tenaga kerja keluarga besarnya untuk ikut berkontribusi dalam bisnis ini, "Saudara-saudara saya kan dari kampung nggak mungkin nyari kerja, apalagi jadi PNS jaman sekarang, iya kan? Walaupun kita keluaran sekolah dari mana, tetep ajah...".

Bisnis keluarga yang banyak melibatkan, memberdayakan dan mempekerjakan keluarga 
bangku ini, beliau nggak setuju bangku ini disimpan diluar, tapi saya tau bangku ini cocok diluar karena lebih aman, lebih nyaman daripada kursi-kursi resmi... bandel aja sendiri. Terus kita taruh, lihat hasilnya bagus, nanti juga lama-lama mereka nilai, oiyaa yaa bagus"

Perbedaan pendapat dirasa lebih rumit jika hal itu terjadi pada sepasang suami istri yang sama-sama terjun pada bisnis keluarga. Bekerja di satu tempat dengan suami membuat tidak leluasa. Keterlibatan suami dalam bisnis keluarga yang dikelola oleh pelaku bisnis keluarga, tak dipungkiri munculnya perbedaan pendapat yang berujung berdebatan. Bahkan tak jarang permasalahan bisnis tersebut terbawa dan dibahas kembali di "rumah". Sepasang suami istri tersebut mengakui sering terlibat pertengkaran kecil, namun mereka yang tak mau berlama-lama dalam kemarahan, begitupun sang Suami, mencoba mencari jalan keluar atas permasalah tersebut dan tidak lagi membawa permasalahan tersebut ke rumah.

Menanggapi perbedaan pendapat ini, Carl R. Rogers dalam Sobur (2013: 106) mengatakan setiap orang bisa berbicara untuk kepentingannya sendiri, ketika kita mampu memahami sudut pandang orang lain, pendapat kita pun harus banyak diubah. Kita juga akan mendapati emosi tidak lagi ada dalam diskusi tersebut, perbedaan berkurang, dan perbedaan yang tetap ada adalah yang rasional dan bisa dipahami.

Menurutnya, solusi yang diberikan adalah dengan menciptakan situasi dimana masing-masing pihak mulai memahami pihak lain dari sudut pandang pihak lain tersebut. Pada prakteknya, hal ini dapat dicapai, bahkan saat perasaanya memuncak, melalui pengaruh dari seseorang yang bersedia memahami setiap sudut pandang dengan penuh empati, dan yang kemudian bertindak sebagai katalis untuk menghasilkan pemahaman yang lebih jauh.

Konsekuensi nyata dari hubungan saling tergantung adalah konflik. Konflik dapat dihasilkan dari kebutuhan divergen yang kuat dari kedua belah pihak atau dari salah persepsi atau salah pengertian. Konflik dapat terjadi saat kedua belah pihak sedang bekerja untuk tujuan yang sama dan umumnya menginginkan hasil yang sangat berbeda.
Dalam hubungan bisnis keluarga, tak dapat dipungkiri konflik bisa saja terjadi. Namun sejauh ini konflik tersebut masih bisa diatasi. Konflik yang ada hanya sebatas konflik intrapersonal atau intrapsikis dan interpersonal. Konflik intrapersonal atau intrapsikis terjadi di dalam diri seorang individu. Sumber-sumber konflik dapat meliputi gagasan, pemikiran, emosi, nilai, kecenderungan, atau gerakan yang terdapat dalam konflik satu sama lain. Sedangkan konflik interpersonal terjadi dalam suatu hubungan rekan kerja, pasangan, saudara, teman, atau tetangga.

Beberapa pelaku mengakui, pemecahan konflik dalam keluarga justru lebih mudah. Karena mereka sudahmengenali dan memahami karakter masing-masing dari anggota keluarga. Bahkan mereka cenderung menghindar dan tidak tidak membesar-besarkan masalah yang sedang dihadapi. Mereka lebih menghargai porsi keadilan masing-masing dan tidak menuntut hal yang berlebih. Misalnya seperti yang dihadapi oleh salah satu informan yang sudah berkecimpung lama sebagai pengelola keuangan bisnis ibunya. Sang kakak informan, yang baru 1 tahun ikut membantu mengelola keuangan bisnis, menginginkan gaji yang lebih besar dari informan tersebut karena merasa lebih berpengalaman dalam memanaj keuangan di Bank, tempat ia bekerja sebelumnya. Untuk menghindari hal yang merugikan hubungan mereka dan bahkan memicu konflik, informan lebih memilih tidak melakukan apa-apa kecuali menyerahkan keputusan tersebut pada ibunya.

Dari beberapa ungkapan yang berhubungan dengan konflik tersebut, dapat ditarik kesimpulan bahwa para pelaku bisnis keluarga cenderung menghindar atau mundur dan cenderung tidak melakukan apapun. Mereka juga cenderung melakukan problem solving untuk meminimalisir konflik yang berkepanjangan atau bahkan menghindari dampak konflik tersebut.

Ketiga, aktivitas komunikasi bisnis dalam mengembangkan bisnis kuliner. Bisnis tidak lepas dari aktivitas komunikasi pemasaran, dimana hal-hal yang menyangkut promosi dan pengenalan menu-menu baru, membangun hubungan dengan supliyer, media partner, dan menjaga loyalitas pelanggan merupakan hal yang perlu dipertimbangkan terlebih hal itu menyangkut pengembangan bisnis kuliner 
dan data sosial tersimpan dalam bahan yang berbentuk dokumentasi. Sifat utama dari data ini tidak terbatas pada ruang dan waktu sehingga memberi peluang kepada peneliti untuk mengetahui hal-hal yang pernah terjadi di wakru silam. Sebagaian besar data yang tersedia adalah berbentuk surat-surat, catatan harian, cendramata, laporan dan lain sebagainya. (Burgin, 2009: 121-122).

Untuk mendapat data yang tepat maka perlu ditentukan informan yang memiliki kompetensi dan sesuai dengan kebutuhan data (purposive). Penelitian ini bertujuan untuk mengetahui bentuk partisipasi, pelaksanaan partisipasi, manfaat partisipasi dan faktor yang mempengaruhi partisipasi dalam pembelajaran. Oleh karena itu, diperlukan subjek yang memenuhi parameter yang dapat mengungkap hal di atas sehingga memungkinkan data dapat diperoleh. Parameternya adalah: (1) Produk kuliner lokal kota Sukabumi yang berkembang, (2) Pelaku bisnis keluarga berusia sekitar 20 sampai dengan 46 tahun dan berkecimpung dalam bisnis keluarga (3) Terjun dalam dunia usaha kuliner lebih dari 3 tahun, (4) Bisnis yang dijalankan memiliki omset minimal sekitar 100 juta per bulannya.

Polkinghorne (dalam Cresswell, 2014: 112) menyarankan agar peneliti melakukan wawancara sedikitnya 5 individu. Dari kelima karakteristik tersebut, peneliti menemukan 5 rumah makan yang sampai saat ini berkembang pesat, yaitu Robby Fahamsyah family owned Rumah Makan Bubur Ayam Bunut, Debby family owned Rumah Makan Sunda dan Lotek, Mega Mustikawati family owned Mami Ungu (Nasi Uduk Ungu), Yayan Jaelani family owned Saung Sobat dan Gerry Girianza family owned Restoran Raffesia. Profil singkat akan dijelaskan dalam tabel sebagai berikut:

Tabel 1. Profil singkat pelaku bisnis keluarga di bidang kuliner

\begin{tabular}{|c|c|c|c|}
\hline No. & $\begin{array}{c}\text { Nama dan Lama } \\
\text { Berkontribusi }\end{array}$ & Hubungan dengan Pemilik & $\begin{array}{c}\text { Manajemen Pengelolaan } \\
\text { Bisnis Keluarga }\end{array}$ \\
\hline 1. & $\begin{array}{l}\text { Robby Fahamsyah, Pusat } \\
\text { Bubur Ayam Bunut, } \\
\text { berkontribusi selama } 8 \text { tahun }\end{array}$ & $\begin{array}{l}\text { Anak kedua dari empat } \\
\text { bersaudara }\end{array}$ & $\begin{array}{l}\text { - Orang tua sbg pebisnis } \\
\text { generasi kedua berperan } \\
\text { mengawasi, } \\
\text { - Anak pertama yang } \\
\text { mengelola. }\end{array}$ \\
\hline 2. & $\begin{array}{l}\text { Debby, Warung Nasi dan } \\
\text { Lotek Ibu Cucu, berkontribusi } \\
\text { selama } 7 \text { tahun }\end{array}$ & $\begin{array}{l}\text { Anak kedua dari empat } \\
\text { bersaudara }\end{array}$ & $\begin{array}{l}\text { - Orang tua sebagai pemilik } \\
\text { usaha, } \\
\text { - Anak pertama mengelola } \\
\text { manajemen, } \\
\text { - Anak kedua mengelola } \\
\text { keuangan. }\end{array}$ \\
\hline 3. & $\begin{array}{l}\text { Mega Mustikawati, Mami } \\
\text { Ungu Resto, berkontribusi } 3 \\
\text { selama tahun }\end{array}$ & $\begin{array}{l}\text { Anak pertama dari tiga } \\
\text { bersaudara }\end{array}$ & $\begin{array}{l}\text { - Orang tua sebagai pemilik } \\
\text { usaha, } \\
\text { - Anak pertama mengelola } \\
\text { operasional dan keuangan. }\end{array}$ \\
\hline 4. & $\begin{array}{l}\text { Yayan Jaelani, Rumah Makan } \\
\text { Sang Sobat, berkontribusi } \\
\text { selama } 3 \text { tahun }\end{array}$ & $\begin{array}{l}\text { Anak kelima dari lima } \\
\text { bersaudara, sebagai adik ipar } \\
\text { dari kakak kedua }\end{array}$ & $\begin{array}{l}\text { - Kaka ipar sebagai pemilik } \\
\text { usaha } \\
\text { - Adik kelima sebagai } \\
\text { penanggung jawab } \\
\text { perusahaan, } \\
\text { - Saudara lain yang } \\
\text { berkontribusi 5.dengan } \\
\text { menjaga kasir dan mengelola } \\
\text { masakan di bagian dapur }\end{array}$ \\
\hline 5. & $\begin{array}{l}\text { Gerry Girianza, Restoran } \\
\text { Rafflesia, berkontribusi } \\
\text { selama } 3 \text { tahun }\end{array}$ & $\begin{array}{l}\text { Anak pertama dari empat } \\
\text { saudara dan juga sebagai cucu } \\
\text { kedua }\end{array}$ & $\begin{array}{l}\text { - Nenek merupakan pendiri } \\
\text { usaha dan penasehat } \\
\text { - Ibu sebagai pengawas dan } \\
\text { pengelola keuangan } \\
\text { - Anak pertama sebagai cucu } \\
\text { kedua, mengelola bidang } \\
\text { marketing dan chef }\end{array}$ \\
\hline
\end{tabular}


besar ini merupakan suatu usaha agar pemenuhan kebutuhan mereka terpenuhi. Menurut intensitasnya, kebutuhan manusia dikelompokkan menjadi 3 macam yaitu: kebutuhan primer, dimana kebutuhan utama atau kebutuhan yang paling penting untuk di penuhi guna memelihara kelangsungan hidup, lalu kebutuhan sekunder sebagai pelengkap (tambahan) yang dipenuhi setelah kebutuhan primer dipenuhi, serta kebutuhan tersier kebutuhan sebagai pelengkap kehidupan manusia yang pemenuhannya dapat di hindarkan dan bersifat prestise, yang artinya mereka yang dapat memenuhi kebutuhan ini akan terangkat derajat atau martabatnya.

Untuk bertahan hidup dimana nilai rupiah yang kian meningkat dan kebutuhan hidup yang harus dipenuhi, lapangan pekerjaan begitu sangat dibutuhkan sebagai alat untuk pencarian rezeki. "Saya berpikir, daripada kita harus mencari pekerjaan, lebih baik harus bisa menciptakan pekerjaan bagi orang lain. Jadi pada prinsipnya, kita bekerja, kita bikin usaha itu atas dasar kebutuhan ekonomi....".

Mereka berpendapat lebih baik menciptakan peluang dan menggerahkan seluruh potensi keluarga besarnya dalam mengelola bisnis kuliner keluarga. Bahkan untuk koki dapur pun, ia tetap men-hire dan melatih saudara-saudaranya untuk bekerja memasak di dapur.

Motif lainnya yaitu motif bakat. Bakat mengandung makna kemampuan bawaan yang merupakan potensi (potential ability) yang masih perlu pengembangan dan latihan lebih lanjut. Karena sifatnya yang masih potensial, bakat memerlukan ikhtiar pengembangan dan pelatihan secara serius dan sistematis agar dapat terwujud (Utami Munandar, 1992: 83). Bakat berbeda dengan kemampuan (ability) yang mengandung makna sebagai daya untuk melakukan sesuatu, sebagai hasil pembawaan dan latihan. Bakat juga berbeda dengan kapasitas yaitu kemampuan yang dapat dikembangkan di masa yang akan datang apabila latihan dilakukan secara optimal (Semiawan \& Utami, 1992: 201).

Bakat adalah mencakup segala faktor yang ada pada individu sejak awal pertama dari kehidupannya, yang kemudian menumbuhkan perkembangan keahlian, kecakapan dan keterampilan khusus tertentu. bakat bersifat laten potensial sepanjang hidup manusia dan dapat di aktifkan potensinya. (Kartono, 1997).

Motif bakat ini dimiliki salah satu informan yang memang sedari kecil hidup dilingkungan yang tidak jauh dari dapur restoran sang Nenek. Ia memiliki darah dari Sang ibu yang berlatarbelakang pendidikan perhotelan bagian room service dan sang Ayah yang berprofesi sebagai chef di sebuah perhotelan, tak heran jika dalam diri informan tersebut tumbuh kecintaan pada sebuah masakan. "Jadi memang tanpa disadari saya dari kecil memang suka di dapur. Baru saya sadar, saya mau kuliah perhotelan itu mungkin pas SMP atau SMA. Terus saya sering di dapur sendiri, masakmasak nggak jelas sebenernya, nasi goreng nggak tau enak nggak tau enggak gitu yah... tapi seneng bikin sesuatu yang tadinya buka apa-apa terus jadi sesuatu gitu..".

Bakat yang dimiliki salah satu informan merupakan kemampuan bawaan sebagai potensi yang masih perlu dikembangkan dan dilatih agar terwujud. Informanyang lahir dari kedua orang tua yang berkecimpung dalam dunia Perhotelan, tumbuh di lingkungan dapur restoran keluarga, serta melanjutkan perkuliahan dijurusan Perhotelan, bakat yang ia miliki merupakan hasil interaksi dari faktor keturunan maupun lingkungan yang akan berkembang jika ia melalui proses belajar.

Kedua, konstruksi makna komunikasi keluarga. Manusia bertindak terhadap sesuatu berdasarkan makna-makna yang ada pada sesuatu itu bagi mereka. Makna tersebut berasal dari "interaksi sosial seseorang dengan orang lain". Makna-makna tersebut disempurnakan di saat proses interaksi sosial berlangsung. Sebuah makna dipelajari melalui interaksi di antara orang-orang, dan makna tersebut muncul karena adanya pertukaran simbol-simbol dalam kelompok sosial.

Komunikasi keluarga adalah suatu pengorganisasian yang menggunakan katakata, sikap tubuh (gesture), intonasi suara, tindakan untuk menciptakan harapan image, ungkapan perasaan serta saling membagi pengertian. Kata-kata, sikap tubuh, intonasi suara dan tindakan, mengandung maksud mengajarkan, mempengaruhi dan memberikan 
dan kofirmasi terlebih dahulu sebelum pengambilan keputusan bisnis diambil. Bahkan beberapa diantaranya sering melibatkan saudaranya yang lain yang tidak terkait langsung dengan bisnis keluarga tersebut. Dalam pengembilan keputusan para informan memiliki caranya tersendiri, diantara melalui diskusi, kondisional dan professional.

Pengambilan keputusan bisnis sering kali melibatkan saudara kandung yang lain seperti kakak atau adik yang bahkan tidak banyak terlibat dalam kegiatan bisnis keluarga. Disatu sisi, pelaku bisnis yang tergolong muda sering kali bertindak secara spontan yang mereka yakini dapat memberikan keuntungan bisnis, maka disini lah perlunya diskusi dengan orang tua sebagai pemilik dan pengawas yang setidaknya mampu memberikan masukanmasukan yang lebih bijak lebih safety dalam pengambilan keputusan.

Bisnis keluarga yang banyak melibatkan tangan-tangan dari personel keluarga besar, mengharuskan untuk tetap professional tanpa memandang siapa yang dihadapi, baik yang lebih tua dan lebih sepuh dari mereka. Berlaku professional dengan tetap menanyakan bagaimana pembukuan, memeriksa jalan keluar masuknya keuangan, dengan terlebih dahulu mengesampingkan masalah keluarga diantara mereka.

Perbedaan usia yang cukup jauh dengan saudaranya yang lain, tidak menjadi masalah bagi sebagian pelaku bisnis keluarga. Mereka berpendapat, bekerja dengan kakakkakaknya yang lebih tua justru mudah, karena mereka saling mengenal watak dan memahami karakteristik dari masing-masing personal. Walaupun usia mereka lebih muda dibandingkan saudara yang lain, mereka tetap saling menghargai kedudukan, ilmu dan pengalaman masing-masing anggota bisnis keluarga.

Untuk hal-hal penting yang berhubungan dengan bisnis, terlebih bila ada perubahan-perubahan besar di restoran, melapor adalah hal yang wajib dilakukan. "Kalo ada perubahan besar, masih perlu approval dari nenek. Tapi kalo misalkan masalah kecil seperti pengurangan menu, penambahan menu, pergantian menu, itu saya langsung ambil keputusan sendiri."
Namun untuk hal kecil yang kiranya bisa diubah dan tidak memperlihatkan perubahan yang begitu besar, biasanya hal tersebut tidak selalu dilaporkan. Hal ini dilakukan karena mereka tidak ingin menambah beban pikiran para orang tua selaku pemilik dan pengawas bisnis keluarga. Sikap orang tua yang tidak jarang membingungkan terlebih usia yang sudah sepuh, menjadikan pelaku bisnis keluarga bertekad untuk meringankan beban mereka.

Untuk melaporkan hal-hal mengenai bisnis tersebut, biasanya pelaku bisnis melakukannya terlebih dahulu kepada kerabat yang lebih dekat, ibu atau ayah sebelum kedua orang tua tersebut melaporkan langsung pada sesepuh. Pelaku tidak pernah langsung melapor kepada kerabat yang lebih jauh, kecuali mereka yang menghubungi pelaku terlebih dahulu.

Hubungan bisnis keluarga yang begitu kompleks, perbedaan pendapat adalah hal yang wajar terjadi. Karenanya, untuk menjaga keseimbangan dalam hubungan bisnis keluarga, mereka membagi tugas untuk masing-masing pengelola. Bisnis keluarga yang dijalani para pelaku tidak secara langsung memiliki susunan organisasi yang tertulis. Salah satu informan bergerak dalam bisnis bubur ayam bersama kedua orang tuanya, bertugas sebagai manager serta mengelola pengembangan dan inovasi, sang Ibu bertugas mengelola keuangan, dan sang Ayah bertugas sebagai penasehat. Walaupun membagi tugas bukan satu-satunya jalan untuk menghindari perbedaan pendapat dengan kedua orang tuanya, informan menjadikan hal tersebut wajar bila ada keinginan orang tuanya tak sesuai dengan apa yang ia pikirkan.

Perbedaan pendapat dengan anggota keluarga sangat yang emosional pun mengharuskan pelaku bisnis keluarga menghadapinya hal tersebut dengan perlahan. Hubungan bisnis dalam keluarga yang dijalani dengan sang Ibu yang sama-sama memiliki background perhotelan misalnya, tidak membuat sulit dalam bertukar pendapat. Justru yang membuatnya cukup sulit dalam membina hubungan adalah dengan pihak ketiga, yaitu sang Nenek. Dalam menghadapi hal tersebut, pelaku mengakui ia sering bersikap "bandel" dalam arti tidak mendengarkan usulan sang Nenek yang ia rasa kurang pas. "Misalkan 


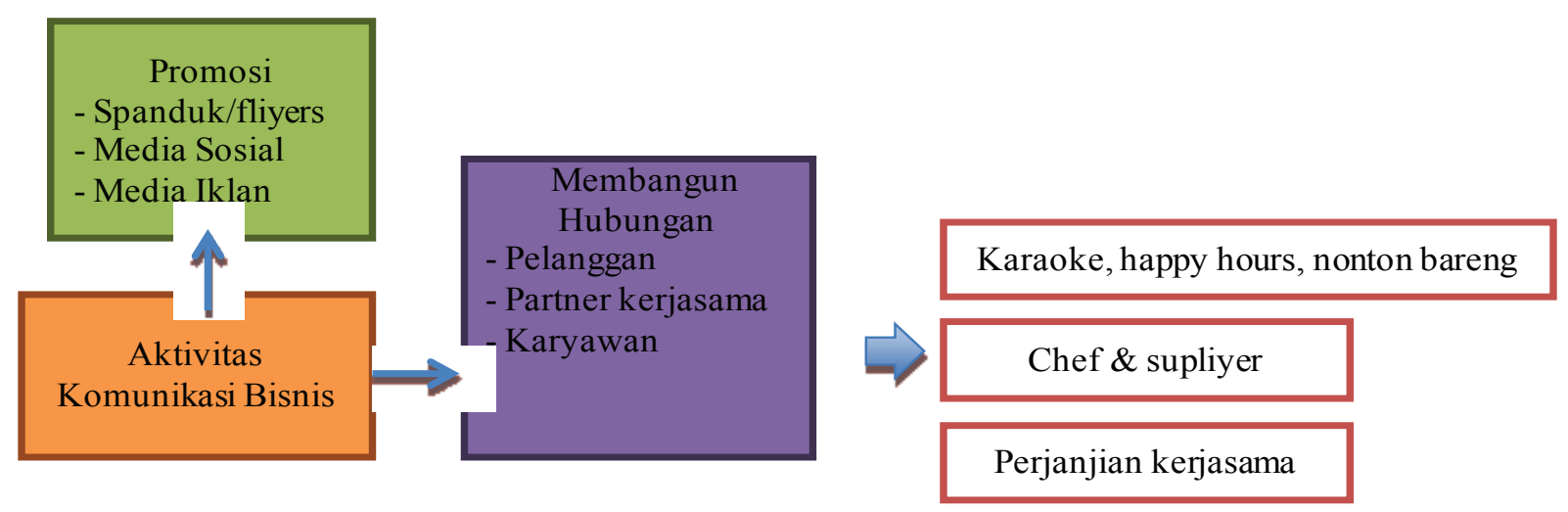

Gambar 3. Model Aktivitas Komunikasi Bisnis Keluarga

Sumber: Penelitian, 2015

tersebut. Aktivitas komunikasi bisnis para pelaku bisnis keluarga ini, dapat divisualisasikan dalam gambar 3 .

Bisnis kuliner sangat erat kaitannya dengan penambahan menu, untuk melakukan promosi atau pengenalan menu baru. Hal yang dilakukan oleh pelaku bisnis keluarga adalah promosi, dengan memasang spandukspanduk yang dipasang beberapa ratus kilometer di jalan sebelum restoran. Mereka memasang baligho yang terpasang di jalan protokoler yang bertuliskan informasi varian menu di restoran. Bahkan membagikan flyier di gedung-gedung instansi pemerintahan, di bank, bahkan di mall.

Berbicara soal penambahan menu, salah satu pelaku bisnis keluarga yang pernah berprofesi sebagai chef yang berpengalaman di dapur hotel-hotel besar ini, terjun ke dapur restoran hanya apabila ada persiapaan proyek menu baru saja. "Iya, kalo itu tergantung sih, tergantung proyek yang ada, misalkan waktu untuk persiapkan menu baru awal tahun kemarin, saya itu mulai develop menu itu dari bulan November, itu ampe tiap hari di dapur, coba bikin menu baru, itu. Setelah akhirnya dapet terus biasanya kasih tester gratis."

Untuk mempromosikan restoran milik keluarganya, informan tetap selektif menggunakan media sosial. Terdapat beragam sosial media seperti twitter, instagram dan path. Namun untuk restoran yang dikelola, mereka hanya memanfaatkan media fans page di facebook karena target pasar restoran ini adalah keluarga dan instansi pemerintahan yang mereka yakini tidak memungkinkan bila mereka menjamah semua media sosial, selain facebook yang memang sudah lama ada.
Selain itu iklan di radio merupakan media yang cukup ampuh untuk mempromosikan restoran yang baru-baru ini buka.

Terakhir, selain promosi melalui media behind the line, beberapa pelaku bisnis keluarga memanfaatkan media lainnya seperti media sosial, media iklan bahkan media Word of Mouth. Ia berpendapat, bila ia dan karyawan restoran mampu memberikan produk terbaik dengan layanan yang memuaskan, maka tak diragukan lagi komunikasi pemasaran dari mulut ke mulut pun akan terjadi dengan begitu mudah.

Selain melakukan promosi menu secara rutin, pelaku bisnis keluarga pun perlu membangun hubungan dengan berbagai pihak untuk menunjang perkembangan terhadap bisnis kuliner yang sedang dijalankan. Berbicara masalah pengembangan bisnis, salah satu informan merasa sangat berterimakasih kepada seorang notaris yang meminjamkannya uang untuk membayar pajak pembelian rumah yang kini dibangun tempat bisnis bubur ayamnya. "Alhamdulillah eta rejeki mah nggak akan kemana, meni baik pisan itu notaris minjemin uang 100 juta coba. Katanya dulu dia sering makan di tempat kita, dulu malah pernah nitip jam dinding buat promosiin kantor notarisnya. Alhamdulillah jadi setelah akad teh baru kita itung-itungan utang jadinya." Hal ini menunjukkan betapa membangun hubungan dengan pelanggan yang sekaligus partner bisnis merupakan suatu hal yang amat penting.

Untuk membangun hubungan yang kuat dengan para pelanggan bisnis maka relationship harus memiliki tiga karakteristik. Pertama, relationship itu adalah suatu proses berkelanjutan yang panjang tidak mungkin membangun suatu relationship hanya dalam 
satu mindotim. Dalam hal ini kita tidak bisa melakukan komunikasi yang sifatnya intim tetapi lebih pada yang sifatnya umum. Kedua adalah komitmen, komitmen akan kuat jika masing-masing pihak rela melakukan investasi, baik investasi dalam uang, waktu, kesetiaan, dan sebagainya. Ketiga, di dalam relationship itu ada ketergantungan, ketergantungan yang baik adalah yang sifatnya volunteer (sukarela) yaitu sebuah kondisi di mana pelanggan merasakan adanya manfaat dan ketergantungan tersebut bukan karena dipaksa oleh pihak lain (Hollensen, 2003: 212).

Membangun hubungan pun dirasa sangat penting untuk melebarkan sayap bisnis. Restoran yang dikelola salah satu informan yang hingga kini memiliki 8 cabang yang tersebar di Sukabumi, sebelumnya diakui informan memang ada beberapa pihak yang mengajukan kerjasama, menawarkan tanah seluas satu setengah hektar untuk digunakan pembangunan bisnis restoran. Setelah melakukan survey dan ACC perjanjian kerjasama bisnis, informan tetap menjalin hubungan baik dengan partner bisnisnya melalui rapat rutin bulanan.

Selain membangun hubungan dengan pelanggan dan partner bisnis, aktivitas pengembangan bisnis dilakukan dengan menjaga loyalitas pelanggan dan hubungan dengan karyawan, koki dan supliyer.

Ditengah gempuran persaingan bisnis kuliner, pebisnis harus putar untuk memikirkan bagaimana caranya mereka bertahan. Untuk menjaga loyalitas pelanggan para pelaku bisnis memiliki suguhan khusus untuk menjaga loyalitas pelanggan, seperti happy hours, mengadakan diskon khusus pada even-even tertentu misalnya valentine dan 17 Agustusan, live music/Karaoke yang dilaksanakan pada akhir pekan atau acara-acara tertentu, dan nonton bareng yang biasanya dilaksanakan setiap hari selasa malam pukul 20.00 WIB.

Karyawan merupakan partner bisnis yang perlu dijaga hubungannya. Salah satu dari pelaku bisnis keluarga sangat diwanti-wanti oleh sang Ibu untuk tetap memperhatikan karyawannya. Bisnis kuliner parasmanan yang terkadang sering menyisakan beberapa masakan yang beresiko basi. Menjelang malam dan tutup toko informan sering membagibagikan masakan yang tersisa kepada karyawannya. "Jadi kalau Mamah sih nekenin biar saya tetap merhatiin kesejahteraan karyawan, karena kan tanpa karyawan juga kita nggak bisa apa-apa."

Selain memperhatikan kesejahteran karyawan, karyawan pun perlu diberi ujian demi menunjang kemampuannya sebagai waiters yang lebih terampil. Informan sebagai pelaku bisnis keluarga, sangat mementingkan hubungan dengan para karyawan yang kebanyakan masih berusia muda dan lulusan SMA. Hari sabtu dan minggu merupakan ujian bagi para karyawan karena biasanya banyak pengunjung yang berdatangan di hari libur.

Bisnis kuliner, tidak lepas dari pembicaraan mengenai hubungan dengan supliyer bahan mentah. Ini adalah hal yang kondisional. Jarak pasar dengan restoran yang cukup dekat terkadang membuat pengelola bisnis lebih memilih belanja di pasar dengan harga yang lebih murah, khususnya bahan-bahan tertentu seperti sayuran dan buah-buahan. Namun untuk beras dan olahan daging dan ikan, mereka memiliki supliyer yang sejak dahulu mereka percaya.

Selain hubungan dengan karyawan dan supliyer, bisnis kuliner sangat erat kaitannya dengan jasa koki atau chef. Beberapa restoran menggunakan jasa koki yang memang membutuhkan tangan-tangan yang ahli untuk menunjang bisnis kulinernya. Namun, ada pula yang memanfaatkan SDM yang sudah ada. Seperti sang Ibu dari informan yang mampu menciptakan resep standar untuk sarapan yang cita rasanya pun tidak kalah enak. Begitu pula dengan restoran lainnya yang memang mengandalkan tangan-tangan kontribusi keluarga besar, untuk bagian dapur yang memasak pun dilatih untuk mampu mengkreasikan masakan-masakan yang sudah menjadi standar menu-menu disana.

\section{SIMPULAN}

Para pelaku bisnis keluarga melakukan suatu tindakan tersebut didorong oleh motif yang berbeda-beda. Motif tersebut diantaranya adalah: motif kepatuhan (obedience motive), kepatuhan terhadap orang tua atau kerabat yang memerlukan kontribusi, motif aktualisasi diri (self actualization motive) adanya perencanaan untuk membuka cabang restoran baru, dimana keinginan untuk mengaktualisasikan diritimbul 
sebagai wujud pribadi yang keberadaannya diperhitungkan ketika berada dalam lingkungan keluarganya dan memanfaatkan potensi yang dimiliki, motif ekonomi (economic motive) bisnis keluarga dengan banyak melibatkan, memberdayakan dan mempekerjakan keluarga untuk menciptakan lapangan pekerjaan sebagai usaha untuk mampu bertahan dan memenuhi kebutuhan hidup, dan motif bakat (aptitude motive) dimana bakat atau kemampuan bawaan merupakan potensi yang masih perlu dikembangkan dan dilatih agar terwujud.

Makna komunikasi keluarga yang dikonstruksi merupakan sebuah tantangan dan kepatuhan bagi pelaku bisnis keluarga. Tantangan seperti, perbedaan usia antara anak dan orang tua yang cukup jauh dimana mereka harus berkolaborasi dalam tugas-tugas pengembangan bisnis, dan kepatuhan dimana sopan santun dalam berkomunikasi, manut atau patuh terhadap masukan atau ide-ide bisnis, sangat penting demi menghindari konflik antar anggota keluarga. Makna yang dikonstruksi pelaku bisnis keluarga tersebut, dapat dinetralisir dengan berbagai cara seperti melakukan obrolan ringan yang sangat bermanfaat untuk mencairkan suasana antara anak dan orang tua yang merujuk pada kehidupan pribadi hingga berakhir pada obrolan mengenai pengembangan bisnis keluarga, pertemuan bisnis keluarga yang biasanya lebih informal, serta rapat keluarga yang bersifat fleksibel yang dilakukan setidaknya 2 minggu sekali. Dari ketiga hal tersebut, ada beberapa poin yang biasanya dapat dihasilkan, seperti pengambilan keputusan yang dapat dilakukan secara diskusi dan professional, melakukan pelaporan kegiatan bisnis, dan pemecahan dari perbedaan pendapat bahkan konflik.

Aktivitas Komunikasi pelaku bisnis keluarga dilakukan salah satunya untuk mengembangkan bisnis, halinimencakuppromosidanmembangun hubungan dengan karyawan, partner bisnis, dan pelanggan. Promosi yang dilakukan para pelaku bisnis keluarga dalam bentuk pemasakan spanduk yang berisi informasi mengenai menumenu baru, membagikan flyiers di beberapa instansi pemerintah, di mall dan bahkan di bank, pemasakan iklan di radio dan media sosial facebook. Untuk membangun hubungan, para pelaku bisnis lebih memperhatikan kesejahteraan karyawan dan juru masak (chef) dengan membagi-bagikan makanan yang tidak habis dijual, membangun hubungan dengan pelanggan dengan memfasilitasi restoran dengan acara karaoke, happy hours, nonton bareng di hari-hari tertentu, membina hubungan dengan partner bisnis dengan membangun perjanjian kerjasama pembukaan cabang baru, dan membina hubungan yang berkesinambungan dengan supliyer bahan-bahan mentah.

Rasa saling memiliki antara anggota keluarga merupakan modal utama yang sekaligus dapat menjerumuskan pada kegagalan dalam menjalankan bisnis keluarga. Oleh karena itu kematangan emosi dan niat baik yang solid merupakan hal yang utama yang harus dimiliki oleh setiap individu pelaku bisnis keluarga.

Pelaku bisnis keluarga harus mampu menyelaraskan kepentingan keluarga dan kepentingan bisnis, antara keinginan keluarga dan business requirements, dengan tujuan agar proses-proses yang ada dalam operasi perusahaan berjalan lancar. Dalam penyelarasan ini kunci utamanya terletak pada upaya menggandengkan nilai perusahaan dan nilai keluarga. Adanya susuan organisasi secara tertulis, lengkap dengan deskripsi kerja. Hal ini memudahkan dalam pembagian tugas dan menyampaian informasi mengenai bisnis, sehingga tidak ada satupun pelaku bisnis keluarga yang dirugikan.

Dan yang terpenting adalah cara berkomunikasi dan penyampaian pesan terhadap orang tua sebagai perintis bisnis, harus didasari oleh kepatuhan terhadap orang yang lebih tua. Menghargai, menghormati dan memahami pendapat orang tua yang walau dirasa kurang pas, mampu memberikan segala penjelasan dengan tidak menyinggung orang tua yang begitu perasa. Menjaga keharmonisan dengan saudara yang lain, walaupun posisi keterlibatan pelaku terhadap bisnis keluarga sangat besar, tetap bergandengan tangan merupakan solusi yang lebih baik.

\section{DAFTAR PUSTAKA}
Cresweel, J. W. (2014). Penelitian kualitatif \& desain riset. Yogyakarta: Pustaka Pelajar.

Collin, P. H. (2002). Dictionary of law, Third edition, Peter Collin Publishing.

Donnelley, R. G. (2002). The family business. 
In Family Business Sourcebook by Craig E. Aronoff, Joseph H. Astrachan, and John L. Ward (eds). $3^{\text {rd }}$ edition. 2002.

Friendly. (2002). Komunikasi dalam keluarga. Jakarta: Family Altar

Gurbuz, G. \& Aykol, S. (2008). Entrepreneurial intentions of young educated public in turkey. Journal of Global Strategic Management, 4(1): 47-56.

Hollensen, S.(2003). Marketing management a relationship approach. New Jersey: Pearson Education Limited - Prentice Hall Inc.

Kartono, K. (1997). Patologi sosial jilid 5. Jakarta: PT.Raja Grafindo Persada.

Kuswarno, E. (2013). Fenomenologi. Bandung: Penerbit Widya Padjadjaran.
Munir. (1994). Hukum bisnis. Bandung: Citra Aditya Bhakti.

Moleong, L. J. (2013). Metodologi penelitian kualitatif. Bandung: Remaja Rosdakarya.

Schutz, A. (1970). On Phenomenology and social relations. Chicago: The University of Chicago Press.

Semiawan, C. \& Utami, M. (1992). Memupuk bakat dan kreativitas siswa menengah, Jakarta: Gramedia.

Slamet, B. (2007). Psikologi umum. Bandung: Remaja Rosdakarya.

Sugiyono. (2013). Metode penelitian kuantitatif kualitatif dan $R$ \& $D$. Bandung: Penerbit Alfabeta.

Sobur, A. (2013). Filsafat komunikasi, tradisi dan metode fenomenologi. Bandung: Remaja Rosdakarya. 